\title{
Notulae to the Italian alien vascular flora: 6
}

Gabriele Galasso', Gianniantonio Domina ${ }^{2}$, Alessandro Alessandrini ${ }^{3}$,

Nicola M.G. Ardenghi ${ }^{4}$, Gianluigi Bacchetta ${ }^{5}$, Sandro Ballelli ${ }^{6}$, Fabrizio Bartolucci ${ }^{7}$, Giuseppe Brundu ${ }^{8}$, Sergio Buono ${ }^{9}$, Giuseppe Busnardo ${ }^{10}$, Giacomo Calvia ${ }^{5}$, Paolo Capece ${ }^{1}$, Marco D’Antraccoli ${ }^{12}$, Luca Di Nuzzo ${ }^{13}$, Emanuele Fanfarillo ${ }^{14}$, Giulio Ferretti ${ }^{13}$, Riccardo Guarino ${ }^{15}$, Duilio Iamonico $^{16}$, Mauro Iberite ${ }^{14}$, Marta Latini ${ }^{14}$, Lorenzo Lazzaro ${ }^{13}$, Michele Lonati ${ }^{17}$, Vanessa Lozano ${ }^{8}$, Sara Magrini ${ }^{18}$, Giacomo Mei ${ }^{19}$, Giuliano $\mathrm{Mereu}^{20}$, Andrea Moro ${ }^{21}$, Michele Mugnai ${ }^{13}$, Gianluca Nicolella ${ }^{22}$, Pier Luigi Nimis ${ }^{21}$, Nicola Olivierii ${ }^{23}$, Riccardo Pennesi ${ }^{21}$, Lorenzo Peruzzi ${ }^{12}$, Lina Podda ${ }^{8}$, Massimiliano Probo ${ }^{24}$, Filippo Prosser ${ }^{25}$, Simone Ravetto Enri ${ }^{17}$, Francesco Roma-Marzio $^{12}$, Alessandro Ruggero ${ }^{26}$, Filippo Scafidi², Adriano Stinca ${ }^{27}$, Chiara Nepi ${ }^{28}$

I Sezione di Botanica, Museo di Storia Naturale di Milano, Corso Venezia 55, 20121 Milano, Italy 2 Dipartimento di Scienze Agrarie, Alimentari e Forestali (SAAF), Università di Palermo, Viale delle Scienze, ed. 4, 90128 Palermo, Italy 3 Istituto Beni Culturali, Regione Emilia-Romagna, Via Galliera 21, 40121 Bologna, Italy 4 Dipartimento di Scienze della Terra e dell'Ambiente, Università di Pavia, Via Sant'Epifanio 14, 27100 Pavia, Italy 5 Centro Conservazione Biodiversità, Dipartimento di Scienze della Vita e dell'Ambiente, Università di Cagliari, Viale Sant'Ignazio da Laconi 13, 09123 Cagliari, Italy 6 Scuola di Bioscienze e Medicina Veterinaria, Università di Camerino, Via Pontoni 5, 62032 Camerino (Macerata), Italy 7 Centro Ricerche Floristiche dell'Appennino (Università di Camerino - Parco Nazionale del Gran Sasso e Monti della Laga), San Colombo, 67021 Barisciano (L'Aquila), Italy 8 Dipartimento di Agraria, Università di Sassari, Viale Italia 39, 07100 Sassari, Italy 9 Via XXV Aprile 6, 01010 Oriolo Romano (Viterbo), Italy 10 Viale XI Febbraio 22, 36061 Bassano del Grappa (Vicenza), Italy II Agenzia Regionale per la Protezione dell'Ambiente della Sardegna (ARPAS), Viale Porto Torres 119, 07100 Sassari, Italy 12 Unità di Botanica, Dipartimento di Biologia, Università di Pisa, Via Derna 1, 56126 Pisa, Italy 13 Dipartimento di Biologia, Università di Firenze, Via G. La Pira 4, 50121 Firenze, Italy 14 Dipartimento di Biologia Ambientale, Sapienza Università di Roma, Piazzale A. Moro 5, 00185 Roma, Italy 15 Sezione di Botanica ed Ecologia Vegetale, Dipartimento di Scienze e Tecnologie Biologiche, Chimiche e Farmaceutiche (STEBICEF), Università di Palermo, Via Archirafi 20, 90123 Palermo, Italy 16 Dipartimento di Pianificazione, Design, Tecnologia dell'Architettura (PDTA), Sapienza Università di Roma, Via Flaminia 72, 00196 Roma, Italy 17 Dipartimento di Scienze Agrarie, Forestali e Alimentari (DISAFA), Università di Torino, Largo P. Braccini 1, 10095 Grugliasco (Torino), Italy 18 Banca del Germoplasma della Tuscia, Università della Tuscia, Largo dell'Università snc, blocco c, 01100

Copyright Gabriele Galasso et al. This is an open access article distributed under the terms of the Creative Commons Attribution License (CC BY 4.0), which permits unrestricted use, distribution, and reproduction in any medium, provided the original author and source are credited. 
Viterbo, Italy 19 Dipartimento di Scienze Agrarie, Alimentari ed Ambientali, Università Politecnica delle Marche, Via Brecce Bianche 10, 60131 Ancona, Italy 20 Via Alghero 17, 08042 Bari Sardo (Nuoro), Italy 21 Dipartimento di Scienze della Vita, Università di Trieste, Via L. Giogieri 10, 34127 Trieste, Italy 22 Via di Valle Melaina 61, 00139 Roma, Italy 23 Via Maestri del Lavoro 40, 64100 Teramo, Italy 24 Grazing Systems, Agroscope, Route de Duillier 50, 1260 Nyon, Switzerland 25 Fondazione Museo Civico di Rovereto, Largo Santa Caterina 41, 38068 Rovereto (Trento), Italy 26 Loc. Parapinta, 07029 Tempio Pausania (Sassari), Italy 27 Dipartimento di Scienze e Tecnologie Ambientali, Biologiche e Farmaceutiche, Università della Campania Luigi Vanvitelli, Via A. Vivaldi 43, 81100 Caserta, Italy 28 Museo di Storia Naturale (Botanica), Sistema Museale di Ateneo, Università di Firenze, Via G. La Pira 4, 50121 Firenze, Italy

Corresponding author: Gabriele Galasso (gabriele.galasso@comune.milano.it)

Academic editor: Stefania Biondi | Received 15 October 2018 | Accepted 25 October 2018 | Published 12 November 2018

Citation: Galasso G, Domina G, Alessandrini A, Ardenghi NMG, Bacchetta G, Ballelli S, Bartolucci F, Brundu G, Buono S, Busnardo G, Calvia G, Capece P, D’Antraccoli M, Di Nuzzo L, Fanfarillo E, Ferretti G, Guarino R, Iamonico D, Iberite M, Latini M, Lazzaro L, Lonati M, Lozano V, Magrini S, Mei G, Mereu G, Moro A, Mugnai M, Nicolella G, Nimis PL, Olivieri H, Pennesi R, Peruzzi L, Podda L, Probo M, Prosser F, Ravetto Enri S, Roma-Marzio F, Ruggero A, Scafidi F, Stinca A, Nepi C (2018) Notulae to the Italian alien vascular flora: 6. Italian Botanist 6: 65-90. https://doi. org/10.3897/italianbotanist.6.30560

\begin{abstract}
In this contribution, new data concerning the distribution of vascular flora alien to Italy are presented. It includes new records, confirmations, exclusions, and status changes for Italy or for Italian administrative regions of taxa in the genera Acalypha, Acer, Canna, Cardamine, Cedrus, Chlorophytum, Citrus, Cyperus, Epilobium, Eucalyptus, Euphorbia, Gamochaeta, Hesperocyparis, Heteranthera, Lemna, Ligustrum, Lycium, Nassella, Nothoscordum, Oenothera, Osteospermum, Paspalum, Pontederia, Romulea, Rudbeckia, Salvia, Sesbania, Setaria, Sicyos, Styphnolobium, Symphyotrichum, and Tradescantia. Nomenclature and distribution updates, published elsewhere, and corrigenda are provided as supplementary material.
\end{abstract}

\title{
Keywords
}

Alien species, floristic data, Italy

\section{How to contribute}

The text for the new records should be submitted electronically to Chiara Nepi (chiara.nepi@unifi.it). The corresponding specimen along with its scan or photograph has to be sent to FI Herbarium: Museo di Storia Naturale (Botanica), Sistema Museale di Ateneo, Via G. La Pira 4, 50121 Firenze (Italy). Those texts concerning nomenclatural novelties (typifications only for accepted names), status changes, exclusions, and confirmations should be submitted electronically to: Gabriele Galasso (gabriele.galasso@comune.milano.it). Each text should be within 2,000 characters (spaces included). 


\section{Floristic records}

\section{Acalypha australis L. (Euphorbiaceae)}

+ (CAS) LAZ: Castrocielo (Frosinone), loc. Capodacqua (WGS84: $41.518520^{\circ} \mathrm{N}$; $13.708890^{\circ} \mathrm{E}$ ), prato, $110 \mathrm{~m}, 23$ September 2016, G. Nicolella, M. Iberite (FI, RO). Casual alien species new for the flora of Lazio.

This record is the first one for peninsular Italy, as the taxon was known only for some northern regions (Galasso et al. 2018a). This Asiatic species was observed growing on the left shore of a small lake characterized by disturbed vegetation, along with Bidens vulgata Greene (Nicolella et al. 2017), Lemna minuta Kunth, Zantedeschia aethiopica (L.) Spreng., and other alien species. The introduction of Acalypha australis in Italy is probably accidental, and related both to plant nursery activities (Banfi and Galasso 2010) and contamination of agricultural seeds (Kravchenko 2008). It naturally colonizes river banks and other wet habitats, and it is a feared weed in agriculture, with special regard to its ability to spread into maize fields (Zuo et al. 2008). This population was also reported in the Acta Plantarum Forum (http://www.floraitaliae. actaplantarum.org/viewtopic.php?t=102122).

E. Fanfarillo, D. Iamonico, M. Iberite, M. Latini, G. Nicolella

\section{Acer saccharinum L. subsp. saccharinum (Sapindaceae)}

+ (CAS) ABR: Teramo (Teramo), Via A. De Gasperi, presso l'alveo del Torrente Vezzola (WGS84: $42.662558^{\circ} \mathrm{N}$; $13.708741^{\circ} \mathrm{E}$ ), margine stradale, ca. $252 \mathrm{~m}, 20$ June 2018, N. Olivieri (FI). - Casual alien subspecies new for the flora of Abruzzo.

Some young individuals grow near a street edge in a cool and shady area located at the base of a slope, on arenaceous soil, not far from the Stream Vezzola, together with Parietaria judaica L. and young individuals of Celtis australis L. subsp. australis, Laurus nobilis L., Quercus pubescens Willd. subsp. pubescens, and Viburnum tinus L. subsp. tinus. The young plants originated from the samaras produced by two trees planted nearby for ornamental purposes. This species is native to the eastern regions of North America and was introduced in Italy in 1760 (Maniero 2015) as an ornamental plant, marked by rapid growth.

N. Olivieri

\section{Canna indica L. (Cannaceae)}

+ (CAS) MAR: San Benedetto del Tronto (Ascoli Piceno), lungo la ferrovia all'interno dell'abitato presso Via G. Sgambati (WGS84: $42.941111^{\circ} \mathrm{N} ; 13.887777^{\circ} \mathrm{E}$ ), margine della massicciata ferroviaria, ca. 6 m, E, 10 July 2018, N. Olivieri (FI). - Casual alien species new for the flora of Marche. 
A group of plants are located on the edge of the railway embankment, close to the Adriatic Sea, on rather damp gravelly substratum, beneath a young individual of Phoenix canariensis $\mathrm{H}$.Wildpret. In the area the herbaceous vegetation is mainly constituted by Equisetum ramosissimum Desf. and Parietaria judaica L.

N. Olivieri

\section{Cardamine occulta Hornem. (Brassicaceae)}

+ (CAS) MAR: Camerino (Macerata), Viale G. Leopardi 14, at the Botanical Garden (WGS84: $43.136004^{\circ} \mathrm{N}$; $13.069947^{\circ} \mathrm{E}$ ), greenhouse soil, synanthropic habitat, 635 m, no exp., 30 March 2018, S. Ballelli, R. Pennesi (FI, CAME); Fabriano (Ancona), Piazzale Santa Maria Maddalena (WGS84: $43.331993^{\circ} \mathrm{N} ; 12.899302^{\circ} \mathrm{E}$ ), flower vases soil, synanthropic habitat, 340 m, no exp., 5 April 2018, S. Ballelli (FI, CAME). Casual alien species new for the flora of Marche.

+ (CAS) UMB: Foligno (Perugia), Via Gran Sasso 23, near Restaurant Winner (WGS84: $42.960197^{\circ} \mathrm{N}$; $12.689901^{\circ} \mathrm{E}$ ), flower vases soil, synanthropic habitat, 230 m, no exp., 23 February 2014, S. Ballelli (FI, CAME). - Casual alien species new for the flora of Umbria.

Several authors reported this taxon under different names, but Marhold et al. (2016) clarified that the oldest name applicable for the so-called "Asian Cardamine flexuosa" is C. occulta. In Italy, C. occulta was first found in Sardegna (Lazzeri et al. 2013, under the name C. flexuosa With. subsp. debilis O.E.Schulz), then in other Italian regions (Toscana and Lombardia: Ardenghi and Mossini 2014, under the name C. flexuosa subsp. debilis; Piemonte: Verloove and Ardenghi 2015, under the name C. hamiltonii G.Don; Veneto: Marhold et al. 2016; Trentino-Alto Adige: Galasso et al. 2016a; Campania: Stinca et al. 2017; Lazio: Galasso et al. 2018b). The present findings broaden its distribution in central Italy both in Marche and Umbria. Cardamine occulta has been found growing together with the similar $C$. hirsuta $\mathrm{L}$. in urban environments, especially in flower pots. Its presence in these regions could date back to several years ago; additionally its distribution may be much broader than reported, given the possible confusion with C. hirsuta (see Šlenker et al. 2018 for differences).

S. Ballelli, R. Pennesi

\section{Cedrus atlantica (Endl.) G.Manetti ex Carrière (Pinaceae)}

+ (NAT) SAR. - Status change from casual to naturalized alien for the flora of Sardegna.

This species is endemic to the Atlas Mountains, in Morocco and Algeria, but it has been used in reforestations and as an ornamental tree in many countries (Farjon 2017). In Sardegna it was reported as cultivated by Pavari and De Philippis (1941), and recently indicated as a casual alien species (Bacchetta et al. 2009, Puddu et al. 2016, Galasso et al. 2018a). Actually, the species is naturalized in those places where it was abundantly introduced since the 1930s, such as the State Forests of Bono, Bultei, Ane- 
la, and Monte Limbara (Pavari and De Philippis 1941), but also in the State Forests of Orgosolo, Arzana, and Villagrande Strisaili (Montes, M. Idolo, Bau Muggeris). In these sites, there is an important renewal and adult trees occur in woodlands, garrigues, heaths, roadsides, and reforestations.

G. Bacchetta, G. Calvia, A. Ruggero

\section{Chlorophytum comosum (Thunb.) Jacques (Asparagaceae)}

+ (CAS) ABR: Teramo (Teramo), bordo di Via C. Battisti (WGS84: $42.659936^{\circ} \mathrm{N}$; $13.703644^{\circ} \mathrm{E}$ ), margine stradale, ca. $268 \mathrm{~m}, 14$ June 2018, N. Olivieri (FI). - Casual alien species new for the flora of Abruzzo.

Some individuals of this species can be found near the edge of the road and the base of a building in a shady and humid site, near a rain gutter downspout, in a central area of the town. Probably these individuals were vegetatively generated from plants grown as ornamentals on surrounding buildings. Chlorophytum comosum is native to southern Africa and is a popular cultivated plant.

N. Olivieri

\section{Citrus $\times$ aurantium L. (Rutaceae)}

+ (CAS) MAR: San Benedetto del Tronto (Ascoli Piceno), presso Viale delle Palme (WGS84: $42.950919^{\circ} \mathrm{N} ; 13.884188^{\circ} \mathrm{E}$ ), aiuola occupata da arbusti di Westringia fruticosa, ca. $8 \mathrm{~m}, 10$ July 2018, $N$. Olivieri (FI). - Casual alien nothospecies new for the flora of Marche.

A young individual has grown within a flowerbed of a public garden, among shrubs of Westringia fruticosa (Willd.) Druce and Melaleuca citrina (Curtis) Dum.Cours. The place is located at short distance from the Adriatic Sea and is protected from cold easterly winds by the presence of Pinus halepensis Mill. subsp. halepensis trees and buildings. The young plant probably originated from seeds produced by an adult specimen cultivated in the gardens not far away. Along the southernmost part of the Marche coast, the cultivation of Citrus xaurantium and other Citrus fruits has been present since the $12^{\text {th }}$ century D.C. (Zavatti 1966, Manzi and Vitelli 2016).

N. Olivieri

\section{Cyperus microiria Steud. (Cyperaceae)}

+ (CAS) TOS: Pisa (Pisa), nei pressi dell'aeroporto (WGS84: $43.691115^{\circ} \mathrm{N}$; $10.412054^{\circ} \mathrm{E}$ ), campi coltivati, ca. $5 \mathrm{~m}, 17$ October 2017, R. Guarino (FI). - Casual alien species new for the flora of Toscana.

This is a late-flowering annual species of eastern Asiatic origin, widely naturalized in Europe and U.S.A. (Verloove 2014). In Italy, it was first collected near Como in 1908 
(Camperio and Fiori 1910) and currently it is recorded as invasive alien in Lombardia and Emilia-Romagna, naturalized in Piemonte and Veneto, and casual in TrentinoAlto Adige and Friuli Venezia Giulia (Galasso et al. 2018a). Our finding, in a regularly disturbed field edge next to the airport of Pisa, is the first record south of the Apennines because a previous record from Calabria was found to be erroneus (Galasso et al. 2016b, 2018a).

R. Guarino, L. Peruzzi

\section{Epilobium brachycarpum C.Presl (Onagraceae)}

+ (NAT) ITALIA (EMR): Bologna (Bologna), scalo merci di Bologna San Donato, tratto compreso tra il Posto A e il Posto B (WGS84: $44.506283^{\circ} \mathrm{N} ; 11.390399^{\circ} \mathrm{E}$ ), pietrisco fine e compattato di natura calcareo-marnosa tra i binari, $50 \mathrm{~m}, 26$ September 2017, leg. A. Alessandrini, det. N.M.G. Ardenghi (FI). - Naturalized alien species new for the flora of Italy (Emilia-Romagna).

Epilobium brachycarpum is a therophyte native to western North America. In Europe, it was first recorded in Spain in 1978 and, by the 1990s, in different countries of the central and north-western parts of the continent: France, Germany, Belgium, and United Kingdom. It colonizes disturbed, dry and warm habitats characterized by shortlived ruderal communities, with a distinct preference for railway areas, where many of the European records come from (Izco 1983, Bönsel and Ottich 2005, Verloove and Lambinon 2009, Gregor et al. 2013, Remacle 2014). It is regarded as an invasive species in central Europe (Nierbauer et al. 2016), its rapid expansion being promoted by the high production of seeds, dispersed by wind and probably vehicles, and the strong competition on bare soils with other ruderal plants (Gregor et al. 2013). The population discovered in Bologna is located at the entrance of the almost disused freight yard of Bologna San Donato that has been one of the most important railway yards in Europe. In summer, E. brachycarpum forms a dense monospecific stand, covering an area of about 50 ha. Due to the population extent, it is likely that the species was introduced years ago, probably through imported freight or railroad cars from France (via the TorinoMilano-Bologna line) or Germany (via the Verona-Bologna line). Photos of the population are available at: http://www.floraitaliae.actaplantarum.org/viewtopic.php?t=99257.

A. Alessandrini, N.M.G. Ardenghi

\section{Eucalyptus polyanthemos Schauer subsp. polyanthemos (Myrtaceae)}

+ (CAS) ITALIA (SAR): Villacidro (Sud Sardegna), Campu s'Isca, Rio Leni (WGS84: $39.39538^{\circ} \mathrm{N} ; 8.65812^{\circ} \mathrm{E}$ ), materassi alluvionali granitico-metamorfici, $329 \mathrm{~m}, 20$ July 2018, G. Bacchetta, G. Brundu, L. Podda (FI, CAG). - Casual alien subspecies new for the flora of Italy (Sardegna). 
This Australian species, identified according to the Centre for Plant Biodiversity Research (2006) and Slee et al. (2015), was introduced in Sardegna for reforestation in the period 1914-1921. It shows a scarce tendency to naturalization, unlike E. camaldulensis Dehnh. subsp. camaldulensis and E. globulus Labill. subsp. globulus, occurring only with a dozen young trees near the reforestation site.

G. Bacchetta, G. Brundu, L. Podda

\section{Euphorbia berteroana Balb. ex Spreng. (Euphorbiaceae)}

- ITALIA (SIC). - Alien species to be excluded from the flora of Italy (Sicilia).

On the basis of the following record concerning E. ophthalmica Pers., this species should be excluded from Italy.

M. Mugnai, L. Di Nuzzo, L. Lazzaro, G. Ferretti

\section{Euphorbia hypericifolia L. (Euphorbiaceae)}

+ (CAS) PUG: Melendugno (Lecce), fraz. Borgagne, nella masseria (WGS84: $40.239834^{\circ} \mathrm{N}$; $\left.18.376283^{\circ} \mathrm{E} \pm 1 \mathrm{Km}\right), 20 \mathrm{~m}$, unica pianta presente nel sito, 23 June 2014, E.S. Mauri (FI sub Chamaesyce hyssopifolia). - Casual alien species new for the flora of Puglia.

On the basis of the following record concerning E. hyssopifolia L., E. hypericifolia should be considered as new for the flora of Puglia. Indeed, the Apulian record of Euphorbia hyssopifolia by Buono et al. (2017) should be referred to E. hypericifolia.

M. Mugnai, L. Di Nuzzo, L. Lazzaro, G. Ferretti

\section{Euphorbia hyssopifolia L. (Euphorbiaceae)}

- ITALIA (PUG, SIC). - Alien species to be excluded from the flora of Italy (Puglia and Sicilia).

Euphorbia hyssopifolia was recorded as new for the flora of Italy by Banfi and Galasso (2014), based on specimens collected in Sicilia, and it was subsequently reported in Puglia by E.S. Mauri in Buono et al. (2017). We analysed the exsiccata from Sicilia and Puglia conserved in FI. These specimens were compared to scans of type specimen and revised according to Ma and Gilbert (2008) and Steinmann et al. (2016). We also submitted the specimens to Victor Steinmann, an expert of Euphorbia sect. Anisophyllum Roep. According to our inquiries, both records correspond to Euphorbia hypericifolia L., a species reported so far in Italy for Toscana and Sicilia (Galasso et al. 2018a). Accordingly, E. hyssopifolia should be excluded from the flora of Italy.

M. Mugnai, L. Di Nuzzo, L. Lazzaro, G. Ferretti 


\section{Euphorbia ophthalmica Pers. (Euphorbiaceae)}

+ (CAS) ITALIA (SIC): Palermo (Palermo), in cultis, in H.B. Panorm copiosa sponte qui crescit (WGS84: ca. $38.112642^{\circ} \mathrm{N} ; 13.374495^{\circ} \mathrm{E}$ ), September 1880, M. Lojacono Pojero (P sub E. berteroana); ibidem, in cultis humentibus subsponte in Hortis Palermo (WGS84: ca. $38.112642^{\circ} \mathrm{N}$; $13.374495^{\circ} \mathrm{E}$ ), October 1882, M. Lojacono Pojero (FI sub E. berteroana); ibidem, subsponte in Hortis Palermo (WGS84: ca. $38.112642^{\circ} \mathrm{N}$; $13.374495^{\circ} \mathrm{E}$ ), September 1883, M. Lojacono Pojero (FI sub E. berteroana); ibidem, subsponte in H.B. Panorm (WGS84: ca. $38.112642^{\circ} \mathrm{N} ; 13.374495^{\circ} \mathrm{E}$ ), August 1886 , s.c. (TO sub E. berteroana); ibidem, culta in R.H.B.P. (WGS84: ca. $38.112642^{\circ} \mathrm{N}$; $13.374495^{\circ} \mathrm{E}$ ), s.d., s.c. (PAL No. 51733 sub E. berteroana); Catania (Catania), als Unkraut im Botanischen Garten Catania [infestante nel giardino botanico di Catania] (WGS84: ca. $37.515680^{\circ} \mathrm{N}$; $15.083732^{\circ} \mathrm{E}$ ), September 1928 , leg. K. Müller sub E. nutans, revidit G. Hügin 1995 sub E. hirta, revidit G. Hügin 1997 sub E. berteroana (STU); Ribera (Agrigento), Azienda Pizzuto, infestante degli agrumeti (WGS84: $\left.37.500000^{\circ} \mathrm{N} ; 13.267000^{\circ} \mathrm{E} \pm 2 \mathrm{Km}\right)$, agrumeti, sporadica, s.d. [1970s: G. Ferro, in verbis], G. Ferro (FI sub E. berteroana); ibidem, Fondo Cipolla, negli agrumeti (WGS84: $37.500000^{\circ} \mathrm{N} ; 13.267000^{\circ} \mathrm{E} \pm 2 \mathrm{Km}$ ), agrumeti, ca. $100 \mathrm{~m}$, s.d. [1970s: G. Ferro, in verbis], G. Ferro (FI sub E. berteroana); ibidem, infestante degli agrumeti (WGS84: $37.500000^{\circ} \mathrm{N} ; 13.267000^{\circ} \mathrm{E} \pm 2 \mathrm{Km}$ ), agrumeti, $200 \mathrm{~m}$, non molto diffusa, s.d. [1970s: G. Ferro, in verbis], G. Ferro (FI sub E. berteroana); ibidem (WGS84: $37.500000^{\circ} \mathrm{N} ; 13.267000^{\circ} \mathrm{E} \pm 2 \mathrm{Km}$ ), ai margini di un frutteto (quasi ruderale), ca. 180 m, s.d. [1970s: G. Ferro, in verbis], G. Ferro (FI sub E. berteroana). - Casual alien species new for the flora of Italy (Sicilia).

We revised the herbarium specimens from Italy referred to E. berteroana Balb. ex Spreng., concluding that they should be referred to E. ophthalmica. Indeed, E. berteroana was reported in Sicilia at the turn of the 20th century by Lojacono Pojero (1907) and cited by Fiori (1926, 1928), Giardina et al. (2007), and Pignatti (1982, 2017). Nevertheless, Galasso et al. (2018a) do not mention E. berteroana as occurring in Italy. We searched for herbarium specimens that could be linked to such reports, retrieving exsiccata preserved in FI, P, PAL, and TO. In addition, we retrieved more recent specimens of E. berteroana in STU, collected in 1928 by K. Müller, and in FI, collected in the 1970s by G. Ferro. Such material was compared to the type material and revised using different identification keys (Burch 1965, Steinmann et al. 2016, Burger and Huft 1995) and the expert opinion of Victor Steinmann. Euphorbia berteroana shows affinities with E. ophthalmica and E. hirta L., but can be clearly distinguished from these species. Indeed, E. berteroana shows ovate-elliptic leaf blades with obtuse apex, while E. hirta and E. ophthalmica leaves show leaf blades generally rhombic, with acute apex. In addition, E. ophthalmica differs from E. hirta in having capitula strictly terminal or on leafy lateral stalks, and stem branching from base to tips. Our conclusion is that the Italian exsiccata correspond to Euphorbia ophthalmica, a species never recorded before for Italy. In addition, based on the revised herbarium specimens, the true E. berteroana was never collected in Italy, and the reports by Lojacono Pojero 
(1907), Fiori (1926, 1928), Giardina et al. (2007), and Pignatti (1982, 2017) should be considered erroneous.

M. Mugnai, L. Di Nuzzo, L. Lazzaro, G. Ferretti

\section{Euphorbia prostrata Aiton (Euphorbiaceae)}

+ (NAT) SAR. - Status change from casual to naturalized alien for the flora of Sardegna.

This is a species native to North America (Pignatti 2017), which behaves as invasive alien in Italy and casual in Sardegna (Galasso et al. 2018a). It was reported from various localities of southern Sardegna by Bocchieri et al. (1982) and Bocchieri (1984), and then confirmed by Arrigoni (2010). Later, Puddu et al. (2016) indicated it as a casual alien in Sardegna, while Camarda et al. (2016) reported it as naturalized. It is widespread in Gallura, Logudoro, Ogliastra, Sulcis-Iglesiente, Sarrabus-Gerrei and Campidano, from sea level to $1,050 \mathrm{~m}$ a.s.l., along roadsides and in fallow land, ruderal places, and gardens, mainly on sandy granitic soils.

G. Bacchetta, G. Calvia, L. Podda, A. Ruggero

\section{Euphorbia thymifolia L. (Euphorbiaceae)}

- ITALIA (LIG, TOS, LAZ). - Alien species to be excluded from the flora of Italy (Liguria, Toscana, and Lazio).

To our knowledge, Euphorbia thymifolia was reported (sub E. thymifolia Burm.) for the first time for the flora of Italy in Toscana by Arcangeli (1894), and subsequently for Lazio and Toscana by Chiovenda (1895). This species was also tentatively recorded by Sommier (1898) for Valle d'Aosta. However, the same author stated that all his previous reports should be actually referred to E. maculata L. instead of E. thymifolia (Sommier 1903), as confirmed in Fiori (1901) for all Italian specimens and recently by Bovio (2014) for Valle d'Aosta. Notwithstanding, E. thymifolia was subsequently reported as a literature record (Viegi and Cela Renzoni 1981, Del Prete et al. 1991, Arrigoni and Viegi 2011), confirmed for Lazio and Toscana as a naturalized alien species and recorded as historical record for Liguria (Galasso et al. 2018a). We revised the specimens collected by Chiovenda (FI and RO) according to Steinmann et al. (2016) and Hügin (1998), and we attributed them to E. maculata (in agreement with Sommier 1903 and Fiori 1901). In addition, we revised herbarium specimens of E. maculata and E. thymifolia in FI, FIAF, PI, and RO, concluding that all these specimens correspond to E. maculata. Accordingly, E. thymifolia should be excluded from the Italian alien flora. These two species are similar, but clearly distinguishable by capsules scarcely exserted from the involucre at maturity in $E$. thymifolia vs., well exserted in E. maculata.

M. Mugnai, L. Di Nuzzo, L. Lazzaro, G. Ferretti 


\section{Gamochaeta argyrinea G.L.Nesom (Asteraceae)}

+ (NAT) SAR: Arzachena (Sassari), Nuraghe La Prisgiona (WGS84: $41.025332^{\circ} \mathrm{N}$; 9.214608 ${ }^{\circ} \mathrm{E}$ ), macchie, $130 \mathrm{~m}, 30$ April 2012, G. Calvia (Herb. Calvia, Berchidda); ibidem, Tomba di Giganti Coddu 'Ecchju (WGS84: $41.030579^{\circ} \mathrm{N} ; 9.212391^{\circ} \mathrm{E}$ ), prati, incolti, 90 m, 30 April 2012, G. Calvia (Herb. Calvia, Berchidda); ibidem, loc. Capichera, dintorni della Tomba di Giganti Coddu 'Ecchju (WGS84: 41.030027 $\mathrm{N}$; 9.212321 ${ }^{\circ} \mathrm{E}$ ), prati, incolti, cigli stradali, 85-90 m, 21 July 2018, G. Calvia (FI, CAG). - Naturalized alien species new for the flora of Sardegna.

Gamochaeta argyrinea is native to North America (Nesom 2006). According to Galasso et al. (2018a), it is a naturalized alien in Toscana. In Sardegna, it was found in the countryside of Arzachena, and collected in April 2012. It is known from at least five localities, but apparently expanding.

G. Calvia

\section{Hesperocyparis arizonica (Greene) Bartel (Cupressaceae)}

+ (CAS) LAZ: Alatri (Frosinone) (WGS84: $41.742540^{\circ} \mathrm{N}$; $\left.13.327508^{\circ} \mathrm{E}\right)$, sotto e nei pressi di rimboschimenti a conifere, $570 \mathrm{~m}, 9$ February 2018, E. Fanfarillo (FI, RO). - Casual alien species new for the flora of Lazio.

This northwestern American species, widely used for ornamental purposes and reforestations, is reported as casual for many Italian regions and as naturalized in Toscana (Galasso et al. 2018a). Many small individuals were observed near and under cultivated plants, colonizing the understory of a degraded conifer plantation.

E. Fanfarillo, D. Iamonico, M. Iberite, M. Latini, G. Nicolella

\section{Hesperocyparis macrocarpa (Hartw. ex Gordon) Bartel (Cupressaceae)}

+ (NAT) LAZ: Alatri (Frosinone) (WGS84: $41.744605^{\circ} \mathrm{N}$; $13.327046^{\circ} \mathrm{E}$ ), sotto e nei pressi di rimboschimenti a conifere, $550 \mathrm{~m}, 9$ February 2018, E. Fanfarillo (FI, RO). - Naturalized alien species new for the flora of Lazio.

So far, this species was reported as casual in Umbria and Sardegna (Galasso et al. 2018a). Many sexually reproductive individuals originated from cultivated plants, some of which are several metres tall. Although not previously observed, the size of the individuals and the occurrence of several fertile generations suggest that the population is self-sustaining. Thus, the species can be considered as naturalized in Lazio.

E. Fanfarillo, D. Iamonico, M. Iberite, M. Latini, G. Nicolella

+ (CAS) MOL: Petacciato (Campobasso), fraz. Marina di Petacciato (WGS84: $\left.42.032463^{\circ} \mathrm{N} ; 14.860958^{\circ} \mathrm{E}\right)$, margine di impianto di rimboschimento costiero, 
ca. 3 m, 16 June 2018, N. Olivieri (FI). - Casual alien species new for the flora of Molise.

Some young individuals of the species grow on the edge of an artificial pine forest composed mainly of Pinus halepensis Mill. subsp. halepensis and Pinus pinea L., along with Acacia saligna (Labill.) H.L.Wendl., Cupressus sempervirens L., Eucalyptus camaldulensis Dehnh. subsp. camaldulensis, and Hesperocyparis macrocarpa. They are located on a sandy soil, in shady areas not far from the Adriatic coast. Hesperocyparis macrocarpa is an American species native to California, where it lives in two small areas southwest of the city of Monterey. The species was introduced in Italy in 1851 (Maniero 2015) and is planted especially in coastal areas as a windbreak.

N. Olivieri

\section{Heteranthera reniformis Ruiz \& Pav. (Pontederiaceae)}

+ (CAS) SAR: Cabras (Oristano), nei pressi dello stagno di Cabras (WGS84: $39.96151^{\circ} \mathrm{N} ; 8.51118^{\circ} \mathrm{E}$ ), risaia, $6 \mathrm{~m}, 9$ August 2017, leg. V. Lozano, P. Capece, G. Brundu, det. G. Brundu (FI, SS). - Casual alien species new for the flora of Sardegna.

Heteranthera reniformis is an annual or pluriannual submerged or floating plant, native to freshwater wetlands of North, Central, and South America (Hussner 2012). This species was introduced accidentally in Europe, probably with seeds of rice, and it is also widely cultivated as ornamental plant.

V. Lozano, P. Capece, G. Brundu

\section{Lemna minuta Kunth (Araceae)}

+ (INV) TOS. - Status change from casual to invasive alien for the flora of Toscana.

Lemna minuta is native to temperate and subtropical areas of America (Banfi and Galasso 2010), and it is recorded as invasive or naturalized alien in almost all Italian Regions (Galasso et al. 2018a). In Toscana, this species was recorded for the first time in the Migliarino-San Rossore-Massaciuccoli Regional Park by Peruzzi and Savio (2011). Although these authors reported the species as casual alien, they suggested to carefully monitor it, hypothesizing an ongoing naturalization process. During field surveys in the same areas, we observed that this species is widely distributed. Moreover, in the meantime, L. minuta was recorded for several other sites in Toscana (Lastrucci et al. 2016, Carta et al. 2018). We noticed that Lemna minuta commonly shares the habitat with the native species $L$. minor L. and/or L. gibba L., generally behaving as a strong competitor. Considering the quick expansion and the severe competition with native species, we retain most appropriate the status of invasive alien in Toscana for L. minuta. 


\section{Ligustrum sinense Lour. (Oleaceae)}

+ (CAS) VDA: Arnad (Aosta), fraz. Arnad le Vieux (WGS84: $45.645338^{\circ} \mathrm{N}$; $7.720963^{\circ} \mathrm{E}$ ), giovani individui naturalizzati nelle zone incolte e muretti a secco presso la sede comunale, 368 m, 15 October 2017, M. Lonati, S. Ravetto Enri, M. Probo (FI). - Casual alien species new for the flora of Valle d'Aosta.

Young individuals were observed in fallows and dry stone walls. They originated from seeds from plants cultivated in a neighbouring garden. This species should be monitored in this Region, since it shows a high invasion potential in the plain forests of the neighbouring Piemonte (Lonati et al. 2014, Vacchiano et al. 2016, Regione Piemonte 2018).

M. Lonati, S. Ravetto Enri, M. Probo

\section{Lycium boerhaviifolium L.f. (Solanaceae)}

+ (NAT) ITALIA (SAR): Cagliari (Cagliari), pressi di Viale Buoncammino (WGS84: $39.221681^{\circ} \mathrm{N} ; 9.115990^{\circ} \mathrm{E}$ ), calcari miocenici, $91 \mathrm{~m}, 23$ July 2018, G. Bacchetta, P.L. Nimis, L. Podda (FI, CAG). - Naturalized alien species new for the flora of Italy (Sardegna).

This species is native to South America (Levin et al. 2011). In the city of Cagliari, it behaves as a ruderal nitrophilous plant, which colonizes urban sites as walls or slopes, mainly on the Miocene sedimentary stones "Pietra Cantone" and "Pietra Forte". To our knowledge, this is the first report as a naturalized alien in Europe.

G. Bacchetta, A. Moro, P.L. Nimis, L. Podda

\section{Nassella tenuissima (Trin.) Barkworth (Poaceae)}

+ (CAS) VEN: Bassano del Grappa (Vicenza), Via Passalacqua (WGS84: $45.771104^{\circ} \mathrm{N}$; $\left.11.742118^{\circ}\right)$, bordo di marciapiede, $130 \mathrm{~m}, 21$ May 2017, leg. G. Busnardo, det. F. Prosser (FI, ROV). - Casual alien species new for the flora of Veneto.

This species of South American origin is increasingly planted in southern Europe, where it shows a tendency to escape from cultivation (Verloove 2005). In Italy, this species was reported, as casual, only from Bolzano (Wilhalm et al. 2017). In Trentino-Alto Adige, it has recently been collected as escaped from cultivation also in the province of Trento (Villa Lagarina, at least 10 tufts born spontaneously in the area surrounding the roundabout - within which the species is cultivated - at the "Rovereto Sud" entrance of the motorway, 4 July 2018, F. Prosser, ROV). In Bassano, a few casual specimens have been noticed on the edge of a sidewalk, certainly deriving from a flowerbed a dozen meters away.

G. Busnardo, F. Prosser 


\section{Nothoscordum borbonicum Kunth (Amaryllidaceae)}

+ (NAT) SAR. - Status change from casual to naturalized alien for the flora of Sardegna. For this Central American species, Ardenghi et al. (2011) proposed the status of casual alien in Sardegna. However, $N$. borbonicum seems actually naturalized, given its abundance in Cagliari and its suburbs, where it colonizes roadsides, fallow land, gardens, ruderal places, and even walls. It has been also found in Olbia (Sassari).

G. Bacchetta, G. Calvia, L. Podda

\section{Oenothera lindheimeri (Engelm. \& A.Gray) W.L.Wagner \& Hoch (Onagraceae)}

+ (CAS) TOS: Capraia Isola (Livorno), Isola di Capraia, spontanea sotto il Castello del paese di Capraia Isola (WGS84: $43.048211^{\circ} \mathrm{N}$; $9.844937^{\circ} \mathrm{E}$ ), in una fessura tra le rocce, 52 m, 19 May 2018, L. Lazzaro, M. Distefano (FI). - Casual alien species new for the flora of Toscana.

Oenothera lindheimeri is a species native to southern North America (Louisiana and Texas), where it is widely cultivated as ornamental. In Italy, it was already recorded as a casual alien in Lombardia, Veneto, Campania, and Puglia (Galasso et al. 2018a). This species is widely cultivated in other sites in Toscana, mainly in urban flowerbeds. The material was identified according to Raven and Gregory (1972).

M. Mugnai, L. Di Nuzzo, L. Lazzaro, G. Ferretti

\section{Osteospermum ecklonis (DC.) Norl. (Asteraceae)}

+ (CAS) ABR: Giulianova (Teramo), prato litoraneo presso giardino privato (WGS84: $42.750277^{\circ} \mathrm{N} ; 13.973872^{\circ} \mathrm{E}$ ), prato litoraneo, ca. $8 \mathrm{~m}, 12$ July 2018, N. Olivieri (FI). - Casual alien species new for the flora of Abruzzo.

Some individuals of this species have developed in an arid coastal meadow occupied by psammophilous herbaceous vegetation dominated by Cenchrus longispinus (Hack.) Fernald, near a private garden. The site is located south of the harbour of Giulianova, not far from the beach. The plants have developed from seeds produced by individuals grown as ornamentals in a nearby garden.

N. Olivieri

\section{Paspalum distichum L. (Poaceae)}

+ (INV) CAL: Scalea (Cosenza), centro (WGS84: $39.815757^{\circ} \mathrm{N} ; 15.787249^{\circ} \mathrm{E}$ ), fessure della pavimentazione, $6 \mathrm{~m}, 20$ August 2014, A. Stinca (PORUN); Roccabernarda (Crotone), Valle Niffi (WGS84: $39.107406^{\circ} \mathrm{N} ; 16.873521^{\circ} \mathrm{E}$ ), torrente, 
122 m, 26 July 2018, A. Stinca (PORUN); ibidem, lungo il Fiume Tacina in corrispondenza di loc. Filicetto (WGS84: $39.116179^{\circ} \mathrm{N} ; 16.860654^{\circ} \mathrm{E}$ ), argine fluviale, $102 \mathrm{~m}, 26$ July 2018, A. Stinca (PORUN); Calopezzati (Cosenza), foce del Torrene Calamitti (WGS84: $39.561422^{\circ} \mathrm{N} ; 16.833549^{\circ} \mathrm{E}$ ), argine fluviale, $1 \mathrm{~m}, 17$ August 2018, A. Stinca (PORUN); Corigliano-Rossano (Cosenza), fraz. Rossano, tra la foce del Fiume Trionto e la loc. Faro Trionto (WGS84: $39.621369^{\circ} \mathrm{N} ; 16.754349^{\circ} \mathrm{E}$ ), terreno fangoso, $4 \mathrm{~m}, 17$ August 2018, A. Stinca (PORUN); Cropalati (Cosenza), lungo il Fiume Trionto (WGS84: $39.510398^{\circ} \mathrm{N} ; 16.732697^{\circ} \mathrm{E}$ ), argine fluviale, 160 m, 18 August 2018, A. Stinca (PORUN); Paludi (Cosenza), loc. V.ne S. Martino (WGS84: $39.539589^{\circ} \mathrm{N} ; 16.688078^{\circ} \mathrm{E}$ ), torrente, $220 \mathrm{~m}, 19$ August 2018, $A$. Stinca (PORUN); Strongoli (Crotone), loc. C. Serra Piani (WGS84: $39.264594^{\circ} \mathrm{N}$; 17.019728 $8^{\circ}$ ), terreno fangoso, $138 \mathrm{~m}, 22$ August 2018, A. Stinca (PORUN); Roggiano Gravina (Cosenza), Lago dell'Esaro (WGS84: $39.638220^{\circ} \mathrm{N} ; 16.160279^{\circ} \mathrm{E}$ ), sponde, 135 m, 23 August 2018, L. Peruzzi (PI No. 011541); Castelsilano (Crotone), Fiume Lese (WGS84: $39.216942^{\circ} \mathrm{N} ; 16.865315^{\circ} \mathrm{E}$ ), argine fluviale, $101 \mathrm{~m}$, 8 October 2018, A. Stinca (PORUN); Caccuri (Crotone), Fiume Lese (WGS84: $39.231899^{\circ} \mathrm{N} ; 16.850924^{\circ} \mathrm{E}$ ), argine fluviale, $125 \mathrm{~m}, 9$ October 2018 , A. Stinca (PORUN); ibidem, Torrente Lepre (WGS84: $\left.39.217925^{\circ} \mathrm{N} ; 16.836326^{\circ} \mathrm{E}\right)$, argine fluviale, $133 \mathrm{~m}, 11$ October 2018, A. Stinca (PORUN); Casabona (Crotone), lungo la Fiumara Vitravo (WGS84: $39.254953^{\circ} \mathrm{N} ; 16.905314^{\circ} \mathrm{E}$ ), argine fluviale, $140 \mathrm{~m}$, 12 October 2018, A. Stinca (PORUN). - Status change from naturalized to invasive alien for the flora of Calabria.

Paspalum distichum is recorded for all Italian regions, with the exception of Valle d'Aosta and Trentino-Alto Adige (Galasso et al. 2018a). The latter authors reported this species as naturalized in Calabria. However, we found large populations of this neophyte mostly along the banks of several rivers, streams, and lakeshores of the provinces of Crotone, Catanzaro, and Cosenza, forming belts of 1 to $60 \mathrm{~m}$. In addition to the places indicated in the samples, we have observed a large population also along the Crocchio River (Cropani, Catanzaro province, WGS84: $\left.38.916399^{\circ} \mathrm{N} ; 16.826309^{\circ} \mathrm{E}\right)$. Accordingly, this species should be considered invasive in Calabria.

A. Stinca, F. Bartolucci, L. Peruzzi

\section{Pontederia cordata L. (Pontederiaceae)}

+ (NAT) LAZ: Sabaudia (Latina), loc. Bella Farnia, Strada Litoranea (WGS84: $41.367494^{\circ} \mathrm{N} ; 12.978081^{\circ} \mathrm{E}$ ), fosso, $110 \mathrm{~m}, 25$ June 2013, M. Iberite (FI, RO). Naturalized alien species new for the flora of Lazio.

This is the first record of this taxon for peninsular Italy. Galasso et al. (2018a) report it as a naturalized alien for Lombardia and Veneto, and Montanari et al. (2015) recorded its occurrence in Emilia-Romagna. The population, still present in 2018, covers an extension of about $5 \mathrm{~m}^{2}$; flowering was observed, but the plants probably reproduce only vegetatively. Pontederia cordata is recognized since many years to be a potentially 
invasive species in Europe, namely because of its clonal growth ability (Weber and Gut 2004). This calls a careful monitoring.

E. Fanfarillo, D. Iamonico, M. Iberite, M. Latini, G. Nicolella

\section{Romulea rosea (L.) Eckl. (Iridaceae)}

+ (NAT) SAR: Cardedu (Nuoro), Monte Ferru (WGS84: $39.743000^{\circ} \mathrm{N} ; 9.624400^{\circ} \mathrm{E}$ $\pm 100 \mathrm{~m}$ ), prato con modesta ritenuta idrica invernale, $540 \mathrm{~m}, \mathrm{SE}$, piante concentrate nel prato, con una buona densità; individui sparsi sono presenti fino a un centinaio di metri di distanza, sconfinando nella rada macchia mediterranea, 23 March 2017, G. Mereu (MSNM); ibidem, propaggine nord-orientale del Monte Ferru, versante E (WGS84: $39.743000^{\circ} \mathrm{N} ; 9.624400^{\circ} \mathrm{E} \pm 100 \mathrm{~m}$ ), prato e bordo della macchia mediterranea, 540 m, SE, 15 April 2018, G. Mereu (FI). - Naturalized alien species confirmed for the flora of Sardegna.

The presence of this species was considered doubtful for Sardegna and for Italy in Galasso et al. (2018a). It appears to be naturalized since a long time in the indicated area. Evidence suggests that the plants were already present in 1992, when the site was subjected to human intervention following the creation of the "Cantiere forestale di Monte Ferru". Considering that there are no other reports for Italy and that the population reported for France has been identified as Romulea arnaudii Moret (Moret at al. 2000), this naturalized population is the only one currently documented in Italy and Europe.

G. Mereu

\section{Rudbeckia triloba L. (Asteraceae)}

+ (CAS) TOS: San Marcello Piteglio (Pistoia), fraz. Maresca, tra le loc. Case Bizzarri e Case Alte (WGS84: $44.053978^{\circ} \mathrm{N} ; 10.857800^{\circ} \mathrm{E}$ ), scarpata erbosa al margine della strada, 866 m, 10 November 2017, G. Ferretti, F. Ferraro (FI). - Casual alien species new for the flora of Toscana.

Rudbeckia triloba is an alien species from North America, recorded in Italy for Valle d'Aosta, Piemonte, Lombardia, Trentino-Alto Adige, and Veneto (Galasso et al. 2018a). It is used as ornamental and the recorded plants may have originated from a private garden. The plants were identified according to Ardenghi and Galasso (2013) and Maslo and Šarić (2018).

M. Mugnai, L. Di Nuzzo, L. Lazzaro, G. Ferretti

\section{Salvia hispanica L. (Lamiaceae)}

+ (CAS) LAZ: Bracciano (Roma), Vigna di Valle, Centro Sportivo dell'Aeronautica Militare presso l'Aeroporto di Vigna di Valle (WGS84: $42.084050^{\circ} \mathrm{N} ; 12.222806^{\circ} \mathrm{E}$ ), 
riva del lago, 157 m, 29 October 2017, leg. S. Buono, det. S. Magrini (FI). - Casual alien species new for the flora of Lazio.

Salvia hispanica, commonly known as 'chia', is a species native to central and southern Mexico and Guatemala (Cahill 2003). This species is increasingly cultivated in Europe for human food, as its seeds are a rich source of omega-3 and other nutraceuticals (Muñoz et al. 2013). The first record of its occurrence as a casual alien in Italy, from Marche, is very recent (Ballelli 2015). Galasso et al. (2018a) recorded this species also for Lombardia, Trentino-Alto Adige, Emilia-Romagna, and Sicilia. A single individual was observed on sandy soil near Lake Bracciano, together with other alien species, such as Amorpha fruticosa L., Datura stramonium L., Pavonia hastata Cav. (Galasso et al. 2017), and Physalis peruviana L. (Galasso et al. 2018b). The plant regularly develops flowers and fruits.

S. Buono, S. Magrini

\section{Sesbania punicea (Cav.) Benth. (Fabaceae)}

+ (NAT) SAR. - Status change from casual to naturalized alien for the flora of Sardegna.

Sesbania punicea, native to South America (Erb 1980), is now widespread in many countries as an ornamental plant, becoming locally invasive. Its first report from Sardegna was by Camarda (1998). After a few years, Brundu et al. (2003) and Camarda et al. (2004) indicated it as naturalized in the island. Later, several authors confirmed the same status (e.g., Podda et al. 2011, Camarda et al. 2016, Puddu et al. 2016), but finally Bacchetta and Podda in Galasso et al. (2018a) reported it as a casual alien. Recently, a new locality on sandy substrata was observed, near the dam along Rio Leni (Villacidro), where about 100 shrubs colonize a slope.

G. Bacchetta, G. Brundu, L. Podda

\section{Setaria italica (L.) P.Beauv. subsp. pycnocoma (Steud.) de Wet (Poaceae)}

+ (CAS) MAR: Acqualagna (Pesaro e Urbino), fraz. Furlo, loc. Abbazia di San Vincenzo al Furlo (WGS84: $43.636404^{\circ} \mathrm{N} ; 12.692410^{\circ} \mathrm{E}$ ), scarpata stradale, $185 \mathrm{~m}, 28$ July 2018, G. Mei (FI, ANC, Herb. G. Mei). - Casual alien subspecies new for the flora of Marche.

The presence of Setaria italica subsp. pycnocoma was not yet reported for Marche (Galasso et al. 2018a). This species has been found in an area previously subjected to weeding of the road margins. Most of the population occurs only along road margins, while a few plants have been observed in the nearby abandoned fields. In Italy, this plant colonizes only strongly anthropized areas (Bossard et al. 2000), such as urban suburbs, abandoned railway tracks, road margins, flowerbeds and, less frequently, recently abandoned fields (Banfi and Galasso 2010, Celesti-Grapow et al. 2009). 


\section{Sicyos angulatus L. (Cucurbitaceae)}

+ (INV) LAZ: Morolo (Frosinone), argini e sponde del Fiume Sacco in loc. Ponte di Morolo (WGS84: $41.652513^{\circ} \mathrm{N}$; $13.218388^{\circ} \mathrm{E}$ ), argini e sponde fluviali, $150 \mathrm{~m}, 8$ September 2018, E. Fanfarillo (RO); Supino (Frosinone), argini e sponde del Fiume Sacco in loc. Ponte di Supino (WGS84: $41.638706^{\circ} \mathrm{N} ; 13.253182^{\circ} \mathrm{E}$ ), argini e sponde fluviali, 147 m, 8 September 2018, E. Fanfarillo (RO); Patrica (Frosinone), sponde del Fiume Sacco in loc. Tomacella (WGS84: $41.608884^{\circ} \mathrm{N}$; $13.290797^{\circ} \mathrm{E}$ ), sponde fluviali, 139 m, 8 September 2018, E. Fanfarillo (RO). - Status change from casual to invasive alien for the flora of Lazio.

This species was first recorded in Lazio in 2002 along the Sacco River in Morolo (Frosinone), where its presence was defined "quite rare" (Salerno et al. 2006). After resurveying the same locality and adjacent ones in 2018 , this taxon appeared widespread along the river, forming dense populations both on the ground and on trees on a surface of about $2 \mathrm{~km}^{2}$, and sparsely invading the roadsides. Further down the river, two new sites of occurrence were found at a distance of 4 and $10 \mathrm{~km}$.

E. Fanfarillo, G. Nicolella

\section{Styphnolobium japonicum (L.) Schott (Fabaceae)}

+ (CAS) ABR: Teramo (Teramo), margine di parcheggio presso la Circonvallazione Ragusa (WGS84: $42.660794^{\circ} \mathrm{N} ; 13.703624^{\circ} \mathrm{E}$ ), margine, ca. $265 \mathrm{~m}, 21$ June 2018, N. Olivieri (FI). - Casual alien species new for the flora of Abruzzo.

The species is present with some young individuals in a narrow belt of uncultivated land at the edge of a car park set in an internal courtyard, between the buildings, located behind the church of Sant'Agostino. These young plants, which may exceed the height of $1 \mathrm{~m}$, originated from the seeds produced by a large individual growing on one side of the parking lot. Styphnolobium japonicum is a tree native to East Asia, which was introduced in Italy in 1799 (Maniero 2015).

N. Olivieri

\section{Symphyotrichum squamatum (Spreng.) G.L.Nesom (Asteraceae)}

+ (INV) CAL: Roggiano Gravina (Cosenza), Lago dell'Esaro (WGS84: 39.638220 N; 16.160279² E), sponde, 135 m, 23 August 2018, L. Peruzzi (PI No. 011540). - Status change from naturalized to invasive alien for the flora of Calabria.

Symphyotrichum squamatum is recorded for all Italian regions, with the exception of Valle d'Aosta (Galasso et al. 2018a). The latter authors reported this species as naturalized in Calabria but, given the extent of occurrence and density observed at the lakeshore, it is better considered as an invasive alien: a narrow belt of $S$. squamatum surrounded a large Paspalum distichum L. population in slightly drier areas, all around the lake. 


\section{Tradescantia pallida (Rose) D.R.Hunt (Commelinaceae)}

+ (CAS) SIC: Misilmeri (Palermo), Via Palmerino (WGS84: $38.035184^{\circ} \mathrm{N}$; $13.455890^{\circ} \mathrm{E}$ ), bordi di marciapiedi, 11 June 2018, F. Scafidi (FI). - Casual alien species new for the flora of Sicilia.

Some young individuals of this species were found along the edges of a sidewalk; they probably originated from seeds produced by cultivated plants in private flowerbeds. This species was likely introduced in Italy for ornamental purposes, and it was so far known as casual alien for Lazio, Calabria, and Sardegna (Galasso et al. 2018a).

F. Scafidi, G. Domina

\section{Nomenclature and distribution updates from other literature sources}

Nomenclature, status, and distribution updates according to Fiori (1902), Leigheb and Cameron-Curry (1999), Zohary and Hopf (2000), Orlandi and Arduini (2010), Levin et al. (2011), Alessandrini et al. (2012), Bona (2015), Montanari et al. (2015), Ardenghi and Polani (2016), Korotkova et al. (2017), Scafidi and Raimondo (2017, 2018), Selvi et al. (2017), Arrigoni (2018), Belyaeva et al. (2018), Brock et al. (2018), Carta et al. (2018), Galasso (2018), Gallo et al. (2018), Gargano (2018), Mayoral et al. (2018), Mosyakin et al. (2018), Motti et al. (2018), Nemati et al. (2018), Nesom (2018), Pellegrini (2018), Pellegrini et al. (2018), Pignatti (2018), Särkinen et al. (2018), Siadati et al. (2018), Sukhorukov et al. (2018), Truzzi (2018), Turland et al. (2018), and corrections to Bartolucci et al. (2018) and Galasso et al. (2018a) are provided in Supplementary material 1.

G. Galasso, F. Bartolucci

\section{Acknowledgements}

We gratefully acknowledge colleagues who provided distribution, nomenclatural and taxonomic suggestions: Enrico Banfi, Alessandro Guiggi, Villiam Morelli, and Robert P. Wagensommer.

\section{References}

Alessandrini A, Fontanesi G, Galasso G, Morelli V, Sturloni S (2012) Integrazioni alla flora del Reggiano con alcune novità per la flora dell'Emilia-Romagna. Informatore Botanico Italiano 44(suppl. 1): 7-12.

Arcangeli G (1894) Compendio della Flora Italiana, Ed. 2. Loescher, Torino, Roma.

Ardenghi NMG, Galasso G (2013) Notulae 166-167. In: Galasso G, Banfi E (Eds) Notulae ad plantas advenas longobardiae spectantes: 3 (141-208). Pagine Botaniche 36(2012): 29-31. 
Ardenghi NMG, Mossini S (2014) Cardamine flexuosa subsp. debilis O.E.Schulz. In: RaabStraube E von, Raus T (Eds) Euro+Med-Checklist Notulae, 3. Willdenowia 44(2): 287299. https://doi.org/10.3372/wi.44.44211

Ardenghi NMG, Parolo G, Di Gregorio B (2011) Notulae: 57-60. In: Barberis G, Nepi C, Peccenini S, Peruzzi L (Eds) Notulae alla flora esotica d'Italia: 4 (54-89). Informatore Botanico Italiano 43(1): 57-60.

Ardenghi NMG, Polani F (2016) La flora della provincia di Pavia (Lombardia, Italia settentrionale). 1. L'Oltrepò Pavese. Natural History Sciences 3(2): 51-79. https://doi.org/10.4081/ nhs.2016.269

Arrigoni PV (2010) Flora dell'Isola di Sardegna, Vol. 3. Carlo Delfino Editore, Sassari.

Arrigoni PV (2018) Flora analitica della Toscana, Vol. 4. Edizioni Polistampa, Firenze.

Arrigoni PV, Viegi L (2011) La flora vascolare esotica spontaneizzata della Toscana. Regione

Toscana, Direzione generale Politiche territoriali, ambientali e per la mobilità, Settore Tutela e valorizzazione delle risorse ambientali, Firenze.

Bacchetta G, Mayoral O, Podda L (2009) Catálogo de la flora exótica de la isla de Cerdeña (Italia). Flora Montiberica 41: 35-61.

Ballelli S (2015) Notula: 286. In: Galasso G, Nepi C, Domina G, Peruzzi L (Eds) Notulae alla flora esotica d'Italia: 12 (244-287). Informatore Botanico Italiano 47(1): 89.

Banfi E, Galasso G (Eds) (2010) La flora esotica lombarda. Museo di Storia Naturale di Milano, Milano, 274 pp. [+ CD-Rom]

Banfi E, Galasso G (2014) Notula: 216. In: Barberis G, Nepi C, Peccenini S, Peruzzi L (Eds) Notulae alla flora esotica d'Italia: 17 (2027-2070). Informatore Botanico Italiano 46(1): 85. Bartolucci F, Peruzzi L, Galasso G, Albano A, Alessandrini A, Ardenghi NMG, Astuti G, Bacchetta G, Ballelli S, Banfi E, Barberis G, Bernardo L, Bouvet D, Bovio M, Cecchi L, Di Pietro R, Domina G, Fascetti S, Fenu G, Festi F, Foggi B, Gallo L, Gottschlich G, Gubellini L, Iamonico D, Iberite M, Jiménez-Mejías P, Lattanzi E, Marchetti D, Martinetto E, Masin RR, Medagli P, Passalacqua NG, Peccenini S, Pennesi R, Pierini B, Poldini L, Prosser F, Raimondo FM, Roma-Marzio F, Rosati L, Santangelo A, Scoppola A, Scortegagna S, Selvaggi A, Selvi F, Soldano A, Stinca A, Wagensommer RP, Wilhalm T, Conti F (2018) An updated checklist of the vascular flora native to Italy. Plant Biosystems 152(2): 179-303. https://doi.org/10.1080/11263504.2017.1419996

Belyaeva IV, Epantchintseva OV, Govaerts RHA, McGinn K, Hunnex J, Kuzovkina YA (2018) The application of scientific names to plants in cultivation: Salix vitellina L. and related taxa (Salicaceae). Skvortsovia 4(2): 42-70.

Bocchieri E (1984) Contributo alle conoscenze floristiche del territorio di Pula (Sardegna meridionale): la fascia costiera dal Rio Santa Margherita al Capo di Pula. Rendiconti del Seminario della Facoltà di Scienze dell'Università di Cagliari 54(1): 143-177.

Bocchieri E, Mulas B, Poledrini A (1982) Segnalazioni floristiche italiane: 151-156. Informatore Botanico Italiano 14(2-3): 283-284.

Bona E (Ed.) (2015) Flora esotica del fiume Oglio e dei suoi principali affluenti a nord del Sebino. Tipografia Brenese, Breno, Brescia.

Bönsel D, Ottich I (2005) Über neue Funde des Kurzfrüchtigen Weidenröschens (Epilobium brachycarpum) in Frankfurt am Main. Botanik und Naturschutz in Hessen 18: 43-54. 
Bossard M, Feranec J, Otahel J (2000) CORINE Land Cover technical guide - Addendum 2000. Technical report No 40. European Enviroment Agency, Copenhagen. http://www. geography.sav.sk/documents/2000-feranec-corine.pdf [accessed 01.07.2018]

Bovio M (2014) Flora vascolare della Valle d'Aosta. Testolin Editore, Sarre, Aosta.

Brock JR, Dönmez AA, Beilstein MA, Olsen KM (2018) Phylogenetics of Camelina Crantz. (Brassicaceae) and insights on the origin of gold-of-pleasure (Camelina sativa). Molecular Phylogenetics and Evolution 127: 834-842. https://doi.org/10.1016/j.ympev.2018.06.031

Brundu G, Camarda I, Satta V (2003) A methodological approach for mapping alien plants in Sardinia (Italy). In: Child LE, Brock JH, Brundu G, Prach K, Pyšek P, Wade M, Williamson M (Eds) Plant invasions: ecological threats and management solutions. Backhuys Publishers, Leiden, 41-62.

Buono V, Manni QG, Barone R, Campagna P, Civita F, Mauri ES, Pasquali G, Rignanese L, Stone AM, Sturloni S, Taneburgo G (2017) Rassegna di segnalazioni notevoli riguardanti la Puglia comparse nel forum Acta Plantarum. ActaPlantarum Notes 5: 61-67.

Burch DG (1965) A taxonomic revision of the genus Chamaesyce (Euphorbiaceae) in the Caribbean. Dissertation, University of Florida. https://doi.org/10.5962/bhl.title.37694

Burger W, Huft M (1995) Flora costaricensis: Family \#113 Euphorbiaceae. Fieldiana, Botany, nuova serie 36: 1-169.

Cahill JP (2003) Ethnobotany of chia, Salvia hispanica L. (Lamiaceae). Economic Botany 57(4): 604-618. https://doi.org/10.1663/0013-0001(2003)057[0604:EOCSHL]2.0.CO;2

Camarda I (1998) Considerazioni su alcune specie di antica e recente introduzione in Sardegna e loro dinamica di diffusione. Biocosme Mésogéen 15(1): 89-108.

Camarda I, Brundu G, Carta L, Manca M, Satta V (2004) Invasive alien plants in the National Parks of Sardinia. In: Camarda I, Manfredo MJ, Mulas F, Teel TL (Eds) Global challenges of parks and protected area management. Proceedings of the 9th ISSRM. Carlo Delfino Editore, Sassari, 111-123.

Camarda I, Cossu TA, Carta L, Brunu A, Brundu G (2016) An updated inventory of the nonnative flora of Sardinia (Italy). Plant Biosystems 150(5): 1106-1118. https://doi.org/10.1 080/11263504.2015.1115438

Camperio C, Fiori A (1910) 1231. Cyperus iria L. var. acutiglumis Fiori. In: Fiori A, Béguinot A (Eds) Schedae ad floram italicam exsiccatam. Series II. Centuriae XIII-XIV. Nuovo Giornale Botanico Italiano, nuova serie 17(4): 582.

Carta A, Forbicioni L, Frangini G, Pierini B, Peruzzi L (2018) An updated inventory of the vascular flora of Elba Island (Tuscan Archipelago, Italy). Italian Botanist 6: 1-22. https:// doi.org/10.3897/italianbotanist.6.26568

Celesti-Grapow L, Pretto F, Brundu G, Carli E, Blasi C (Eds) (2009) A thematic contribution to the National Biodiversity Strategy. Plant invasion in Italy, an overview. Ministry for the Environment Land and Sea Protection, Nature Protection Directorate, Rome, 32 pp. [+CD-Rom]

Centre for Plant Biodiversity Research (CPBR) (2006) EUCLID. Eucalypts of Australia. Third Edition (DVD-Rom). CSIRO Publishing, Collingwood.

Chiovenda E (1895) Delle Euforbie della sezione Anisophyllum appartenenti alla flora italiana. Bullettino della Società Botanica Italiana 1895: 61-66. 
Del Prete C, Balderi F, Garbari F (1991) Geobotanical research on Mount Pisano (Tuscany, Italy): 8. A preliminary checklist of the vascular flora. Atti della Società Toscana di Scienze Naturali, Memorie, Serie B 97(1990): 121-192.

Erb HE (1980) The natural enemies and distribution of Sesbania punicea (Cav.) Benth. in Argentina. In: Neser S, Cairns ALP (Eds) Proceedings of the third National Weeds Conference of South Africa. A.A. Balkema, Cape Town, 205-210.

Farjon A (2017) A handbook of the world's conifers. Second, revised edition. Brill, Leiden, Boston.

Fiori A (1901) Euphorbiaceae. In: Fiori A, Béguinot A (Eds) Flora analitica d'Italia, Vol. 2(2).

Tipografia del Seminario, Padova, 272-292.

Fiori A (1902) Asclepiadaceae. In: Fiori A, Béguinot A (Eds) Flora analitica d'Italia, Vol. 2(3).

Tipografia del Seminario, Padova, 344-347.

Fiori A (1926) Nuova flora analitica d'Italia, Vol. 2(2). Tipografia M. Ricci, Firenze, 161-320.

Fiori A (1928) Nuova flora analitica d'Italia, Vol. 2(6). Tipografia M. Ricci, Firenze, 801-944.

Galasso G (2018) Notulae redazionali 388-397. In: Galasso G, Banfi E (Eds) Notulae ad plantas advenas Longobardiae spectantes: 7 (365-397). Pagine Botaniche 40(2017): 46-50.

Galasso G, Conti F, Peruzzi L, Ardenghi NMG, Banfi E, Celesti-Grapow L, Albano A, Alessandrini A, Bacchetta G, Ballelli S, Bandini Mazzanti M, Barberis G, Bernardo L, Blasi C, Bouvet D, Bovio M, Cecchi L, Del Guacchio E, Domina G, Fascetti S, Gallo L, Gubellini L, Guiggi A, Iamonico D, Iberite M, Jiménez-Mejías P, Lattanzi E, Marchetti D, Martinetto E, Masin RR, Medagli P, Passalacqua NG, Peccenini S, Pennesi R, Pierini B, Podda L, Poldini L, Prosser F, Raimondo FM, Roma-Marzio F, Rosati L, Santangelo A, Scoppola A, Scortegagna S, Selvaggi A, Selvi F, Soldano A, Stinca A, Wagensommer RP, Wilhalm T, Bartolucci F (2018a) An updated checklist of the vascular flora alien to Italy. Plant Biosystems 152(3): 556-592. https://doi.org/10.1080/11263504.2018.1441197

Galasso G, Domina G, Adorni M, Ardenghi NMG, Banfi E, Bedini G, Bertolli A, Brundu G, Calbi M, Cecchi L, Cibei C, D’Antraccoli M, De Bastiani A, Faggi G, Ghillani L, Iberite M, Latini M, Lazzeri V, Liguori P, Marhold K, Masin R, Mauri S, Mereu G, Nicolella G, Olivieri N, Peccenini S, Perrino EV, Peruzzi L, Petraglia A, Pierini B, Prosser F, RomaMarzio F, Romani R, Sammartino F, Selvaggi A, Signorile G, Stinca A, Verloove F, Nepi C (2016a) Notulae to the Italian alien vascular flora: 1. Italian Botanist 1: 17-37. https://doi. org/10.3897/italianbotanist.1.8777

Galasso G, Domina G, Adorni M, Ardenghi NMG, Bonari G, Buono S, Cancellieri L, Chianese G, Ferretti G, Fiaschi T, Forte L, Guarino R, Labadessa R, Lastrucci L, Lazzaro L, Magrini S, Minuto L, Mossini S, Olivieri N, Scoppola A, Stinca A, Turcato C, Nepi C (2018b) Notulae to the Italian alien vascular flora: 5. Italian Botanist 5: 45-56. https://doi. org/10.3897/italianbotanist.5.25910

Galasso G, Domina G, Ardenghi NMG, Arrigoni P, Banfi E, Bartolucci F, Bonari G, Buccomino G, Ciaschetti G, Conti F, Coppi A, Di Cecco V, Di Martino L, Guiggi A, Lastrucci L, Leporatti ML, López Tirado J, Maiorca G, Mossini S, Olivieri N, Pennesi R, Romiti B, Scoppola A, Soldano A, Stinca A, Verloove F, Villa M, Nepi C (2016b) Notulae to the Italian alien vascular flora: 2. Italian Botanist 2: 55-71. https://doi.org/10.3897/italianbotanist. 2.11144 
Galasso G, Domina G, Bonari G, Buono S, Chianese G, Cortesi G, Frangini G, Iamonico D, Olivieri N, Peruzzi L, Pierini B, Roma-Marzio F, Scoppola A, Soldano A, Stinca A, Tomaselli V, Veronico G, Nepi C (2017) Notulae to the Italian alien vascular flora: 4. Italian Botanist 4: 33-41. https://doi.org/10.3897/italianbotanist.4.21666

Gallo L, Guiggi A, Perazza G, Prosser F (2018) Phedimus kamtschaticus (Crassulaceae) e Trichocereus candicans (Cactaceae), nuove esotiche casuali per l'Italia osservate al M. Brione (Trentino-Alto-Adige). Annali del Museo Civico di Rovereto. Sezione: Archeologia, Storia Scienze Naturali 32(2016): 207-216.

Gargano ML (2018) The genus Tamarix (Tamaricaceae) in Apulia (southern Italy). Flora Mediterranea 28: 137-143. https://doi.org/10.7320/FlMedit28.137

Giardina G, Raimondo FM, Spadaro V (2007) A catalogue of plants growing in Sicily. Bocconea 20: 5-582.

Gregor T, Bönsel D, Starke-Ottich I, Tackenberg O, Wittig R, Zizka G (2013) Epilobium brachycarpum: a fast-spreading neophyte in Germany. Tuexenia 33: 259-283.

Hügin G (1998) Die Gattung Chamaesyce in Europa. Bestimmungsschlüssel mit taxonomischnomenklatorischen Anmerkungen. Feddes Repertorium 109(3-4): 189-223. https://doi. org/10.1002/fedr.19981090302

Hussner A (2012) Alien aquatic plant species in European countries. Weed Research 52(4): 297-306. https://doi.org/10.1111/j.1365-3180.2012.00926.x

Izco J (1983) Epilobium paniculatum nueva adventicia para Europa. Candollea 38(1) (1982): 309-315.

Korotkova N, Borsch T, Arias S (2017) A phylogenetic framework for the Hylocereeae (Cactaceae) and implications for the circumscription of the genera. Phytotaxa 327(1): 1-46. https://doi.org/10.11646/phytotaxa.327.1.1

Kravchenko OE (2008) Acalypha australis. In: Afonin AN, Greene SL, Dzyubenko NI, Frolov AN (Eds) Interactive Agricultural Ecological Atlas of Russia and Neighboring Countries. Economic Plants and their Diseases, Pests and Weeds [Online]. http://www.agroatlas.ru/ en/content/weeds/Acalypha_australis/ [accessed 01.07.2018]

Lastrucci L, Valentini E, Dell'Olmo L, Vietina B, Foggi B (2016) Hygrophilous vegetation and habitats of conservation interest in the area of the Lake Porta (Tuscany, Central Italy). Atti della Società Toscana di Scienze Naturali, Memorie, Serie B 122(2015): 131-146. https:// doi.org/10.2424/ASTSN.M.2015.12

Lazzeri V, Mascia F, Sammartino F, Campus G, Caredda A, Carlesi V, Fois M, Gestri G, Mannocci M, Mazzoncini V, Lombrańa AC, Santinelli M (2013) Novità floristiche per le regioni Sardegna e Toscana. ActaPlantarum Notes 2: 42-59.

Leigheb G, Cameron-Curry V (1999) Observations on the presence of Danaus chrysippus (Linné, 1758) in the Mediterranean area, with special reference to Italy (Lepidoptera, Danaidae). Linneana Belgica 17(2): 61-68.

Levin RA, Bernardello G, Whiting C, Miller JS (2011) A new generic circumscription in the tribe Lycieae (Solanaceae). Taxon 60(3): 681-690.

Lojacono Pojero M (1907) Flora Sicula, Vol. 2(2). Tipo-Litografia S. Bizzarrilli, Palermo.

Lonati M, Meloni F, Vacchiano G, Ferrarato M (2014) Nota floristica piemontese n. 593. Ligustrum sinense Lour. (Oleaceae). In: Selvaggi A, Soldano A, Pascale M, Dellavedova R (Eds) Note Floristiche Piemontesi n. 545-604. Rivista Piemontese di Storia Naturale 35: 401. 
Ma JS, Gilbert MG (2008) Euphorbia Linnaeus. In: Wu ZY, Raven PH, Hong DY (Eds) Flora of China, Vol. 11. Science Press, Beijing, Missouri Botanical Garden Press, St. Louis, 288-313. Maniero F (2015) Cronologia della flora esotica italiana. Leo S. Olschki, Firenze.

Manzi A, Vitelli G (2016) Giardini d'aranci sull'Adriatico. L'agrumicoltura nelle Marche: aspetti colturali e artistici. Livi Editore, Fermo.

Marhold K, Šlenker M, Kudoh H, Zozomová-Lihová J (2016) Cardamine occulta, the correct species name for invasive Asian plants previously classified as $C$. flexuosa, and its occurrence in Europe. PhytoKeys 62: 57-72. https://doi.org/10.3897/phytokeys.62.7865

Maslo S, Šarić Š (2018) Three-lobed coneflower Rudbeckia triloba L. (Compositae): new alien species in the flora of Bosnia and Herzegovina. Glasnik Hrvatskog Botaničkog Društva 6(1): 8-12.

Mayoral O, Mascia F, Podda L, Laguna E, Fraga P, Rita J, Frigau L, Bacchetta G (2018) Alien plant diversity in Mediterranean wetlands: a comparative study within Valencian, Balearic and Sardinian floras. Notulae Botanicae Horti Agrobotanici Cluj-Napoca 46(2): 317-326. https://doi.org/10.15835/nbha46210470

Montanari S, Faggi G, Bagli L, Sirotti M, Alessandrini A (2015) Aggiornamenti floristici per la Romagna. Terza serie. Quaderno di Studi e Notizie di Storia Naturale della Romagna 42: 9-30.

Moret J, Guern M, Baudoin R, Baudiere A (2000) Etude phénétique du genre Romulea (Iridaceae) en France. Monde des Plantes 95(468): 24-30.

Mosyakin SL, Verloove F, Boiko GV (2018) The correct authorship and nomenclature of $A r$ temisia umbrosa (Asteraceae), with comments on some misapplied names and distribution of the species in eastern Europe. Ukrainian Botanical Journal 75(3): 213-229. https://doi. org/10.15407/ukrbotj75.03.213

Motti R, Esposito A, Stinca A (2018) New additions to the exotic vascular flora of Campania (southern Italy). Annali di Botanica, nuova serie 8: 76-85. https://doi.org/10.4462/annbotrm-14156

Muñoz LA, Cobos A, Diaz O, Aguilera JM (2013) Chia seed (Salvia hispanica): an ancient grain and a new functional food. Food Reviews International 29(4): 394-408. https://doi. org/10.1080/87559129.2013.818014

Nemati Z, Blattner FR, Kerndorff H, Erol O, Harpke D (2018) Phylogeny of the saffron-crocus species group, Crocus series Crocus (Iridaceae). Molecular Phylogenetics and Evolution 127: 891-897. https://doi.org/10.1016/j.ympev.2018.06.036

Nesom GL (2006) Gamochaeta Weddell. In: Flora of North America Editorial Committee (Ed.) Flora of North America North of Mexico, Vol. 19. Oxford University Press, New York, Oxford, 431-438.

Nesom GL (2018) Erigeron floribundus and E. sumatrensis (Asteraceae) in the USA and Mexico. Phytoneuron 2018-27: 1-19.

Nicolella G, Antonelli A, Bamonte R, Bececco I, Carbini D, De Santis E, Faggi G, Maggioni L, Molinaro F, Sesto F, Ardenghi NMG (2017) Rassegna di segnalazioni notevoli riguardanti alcune regioni dell'Italia centro-meridionale comparse nel forum Acta Plantarum. ActaPlantarum Notes 5: 56-60.

Nierbauer KU, Paule J, Zizka G (2016) Invasive tall annual willowherb (Epilobium brachycarpum C. Presl) in Central Europe originates from high mountain areas of western North 
America. Biological Invasions 18(11): 3265-3275. https://doi.org/10.1007/s10530-0161216-0

Orlandi C, Arduini I (2010) Note ad integrazione della flora di San Rossore (Pisa). Informatore Botanico Italiano 42(2): 473-477.

Pavari A, De Philippis A (1941) La sperimentazione di specie forestali esotiche in Italia. Risultati del primo ventennio. Annali della Sperimentazione Agraria 38: 1-648.

Pellegrini MOO (2018) Wandering throughout South America: taxonomic revision of Tradescantia subg. Austrotradescantia (D.R.Hunt) M.Pell. (Commelinaceae). PhytoKeys 101: 1-97. https://doi.org/10.3897/phytokeys.101.25057

Pellegrini MOO, Horn CN, Almeida RF (2018) Total evidence phylogeny of Pontederiaceae

(Commelinales) sheds light on the necessity of its recircumscription and synopsis of Pontederia L. PhytoKeys 108: 25-83. https://doi.org/10.3897/phytokeys.108.27652

Peruzzi L, Savio L (2011) Notula: 83. In: Barberis G, Nepi C, Peccenini S, Peruzzi L (Eds)

Notulae alla flora esotica d'Italia: 4 (54-89). Informatore Botanico Italiano 43(1): 149.

Pignatti S (1982) Flora d'Italia, Vol. 2. Edagricole, Bologna.

Pignatti S (2017) Flora d'Italia, Ed. 2, Vol. 2. Edagricole, Milano.

Pignatti S (2018) Flora d'Italia, Ed. 2, Vol. 3. Edagricole, Milano.

Podda L, Fraga I, Arguimbau P, Mascia F, Mayoral García-Berlanga O, Bacchetta G (2011) Comparison of the invasive alien flora in continental islands: Sardinia (Italy) and Balearic Islands (Spain). Rendiconti Lincei. Scienze Fisiche e Naturali 22(1): 31-45. https://doi. org/10.1007/s12210-010-0112-2

Puddu S, Podda L, Mayoral O, Delage A, Hugot L, Petit Y, Bacchetta G (2016) Comparative analysis of the alien vascular flora of Sardinia and Corsica. Notulae Botanicae Horti Agrobotanici Cluj-Napoca 44(2): 337-346. doi:10.15835/nbha44210491

Raven PH, Gregory DP (1972) A revision of the genus Gaura (Onagraceae). Memoirs of the Torrey Botanical Club 23(1): 1-96.

Regione Piemonte (2018) Le specie vegetali esotiche invasive. Black List-Management List (Gestione). http://www.regione.piemonte.it/ambiente/tutela_amb/esoticheInvasive.htm [accessed 19.07.2018]

Remacle A (2014) Epilobium brachycarpum (Onagraceae) et Chondrilla juncea (Asteraceae), néophytes établis à Arlon (province de Luxembourg, Belgique). Dumortiera 105: 9-12.

Salerno G, Ceschin S, Notamurzi C, Iannuzzi E (2006) Notula: 1262. In: Conti F, Nepi C, Scoppola A (Eds) Notulae alla checklist della flora vascolare italiana: 2 (1192-1266). Informatore Botanico Italiano 38(1): 212.

Särkinen T, Poczai P, Barboza GE, van der Weerden GM, Baden M, Knapp S (2018) A revision of the Old World black nightshades (Morelloid clade of Solanum L., Solanaceae). PhytoKeys 106: 1-223. https://doi.org/10.3897/phytokeys.106.21991

Scafidi F, Raimondo FM (2017) Principi di spontaneizzazione in Sicilia di Talinum paniculatum (Talinaceae). Quaderni di Botanica Ambientale e Applicata 26(2015): 23-25.

Scafidi F, Raimondo FM (2018) First record of Pilea microphylla (Urticaceae) in Sicily. Flora Mediterranea 28: 79-84. https://doi.org/10.7320/FlMedit28.079 
Selvi F, Di Fazio L, Ferli S, Carrari E (2017) Contributo alla conoscenza floristica della valle del Torrente Sambre (Fiesole, Toscana). Atti della Società Toscana di Scienze Naturali, Memorie, Serie B 123(2016): 41-63.

Siadati S, Salmaki Y, Mehrvarz SS, Heubl G, Weigend M (2018) Untangling the generic boundaries in tribe Marrubieae (Lamiaceae: Lamioideae) using nuclear and plastid DNA sequences. Taxon 67(4): 770-783. https://doi.org/10.12705/674.6

Slee AV, Brooker MIH, Duffy SM, West JG (2015) EUCLID. Eucalypts of Australia. Fourth Edition. Available on line at: http://keyserver.lucidcentral.org:8080/euclid/data/02050e020108-490e-8900-0e0601070d00/media/Html/index.htm [accessed 29.09.2018]

Šlenker M, Zozomová-Lihová J, Mandáková T, Kudoh H, Zhao Y, Soejima A, Yahara T, Skokanová K, Španiel S, Marhold K (2018) Morphology and genome size of the widespread weed Cardamine occulta: how it differs from cleistogamic C. kokaiensis and other closely related taxa in Europe and Asia. Botanical Journal of the Linnean Society 187(3): 456-482. https://doi.org/10.1093/botlinnean/boy030

Sommier S (1898) Aggiunte alla florula di Capraia. Nuovo Giornale Botanico Italiano, nuova serie 5(1): 106-139.

Sommier S (1903) La flora dell'Arcipelago Toscano. Nota II. Nuovo Giornale Botanico Italiano, nuova serie 10(2): 133-200.

Steinmann VW, Morawetz JJ, Berry PE, Peirson JA, Yang Y (2016) Euphorbia Linnaeus sect. Anisophyllum Roeper. In: Flora of North America Editorial Committee (Ed.) Flora of North America North of Mexico, Vol. 12. Oxford University Press, New York, Oxford. http:// www.efloras.org/florataxon.aspx?flora_id=1\&taxon_id=318097 [accessed 01.07.2018]

Stinca A, Chianese G, D’Auria G, Del Guacchio E, Fascetti S, Perrino EV, Rosati L, Salerno G, Santangelo A (2017) New alien vascular species for the flora of southern Italy. Webbia 72(2): 295-301. https://doi.org/10.1080/00837792.2017.1349236

Sukhorukov AP, Kushunina M, El Mokni R, Goñalonsd LS, El Aounie MH, Daniel TF (2018) Chorological and taxonomic notes on African plants, 3. Botany Letters 165(2): 228-240. https://doi.org/10.1080/23818107.2018.1465467

Truzzi A (2018) Notulae 373-376. In: Galasso G, Banfi E (Eds) Notulae ad plantas advenas Longobardiae spectantes: 7 (365-397). Pagine Botaniche 40 (2017): 32-37.

Turland NJ, Wiersema JH, Barrie FR, Greuter W, Hawksworth DL, Herendeen PS, Knapp S, Kusber W-H, Li D-Z, Marhold K, May TW, McNeill J, Monro AM, Prado J, Price MJ, Smith GF (Eds) (2018) International Code of Nomenclature for algae, fungi, and plants (Shenzhen Code) adopted by the Nineteenth International Botanical Congress Shenzhen, China, July 2017. Regnum Vegetabile 159: 1-254. https://doi.org/10.12705/Code.2018

Vacchiano G, Meloni F, Ferrarato M, Freppaz M, Chiaretta G, Motta R, Lonati M (2016) Frequent coppicing deteriorates the conservation status of black alder forests in the Po plain (northern Italy). Forest Ecology and Management 382: 31-38. https://doi.org/10.1016/j. foreco.2016.10.009

Verloove F (2005) A synopsis of Jarava Ruiz \& Pav. and Nassella E. Desv. (Stipa L. s.l.) (Poaceae: Stipeae) in southwestern Europe. Candollea 60(1): 97-117. 
Verloove F (2014) A conspectus of Cyperus s.l. (Cyperaceae) in Europe (incl. Azores, Madeira and Canary Islands), with emphasis on non-native naturalized species. Webbia 69(2): 179223. doi:10.1080/00837792.2014.975013

Verloove F, Ardenghi NMG (2015) New distributional records of non-native vascular plants in northern Italy. Natural History Sciences 2(1): 5-14. https://doi.org/10.4081/nhs.2015.219

Verloove F, Lambinon J (2009) Epilobium brachycarpum (Onagraceae), xénophyte américaine naturalisée dans le département du Nord (France). Dumortiera 96: 17-19.

Viegi L, Cela Renzoni G (1981) Flora esotica d'Italia: le specie presenti in Toscana. Consiglio Nazionale delle Ricerche, Collana «Promozione della qualità dell'ambiente», Pavia, $\mathrm{AQ} / 1 / 132$.

Weber E, Gut D (2004) Assessing the risk of potentially invasive plant species in central Europe. Journal for Nature Conservation 12(3): 171-179. https://doi.org/10.1016/j. jnc.2004.04.002

Wilhalm T, Aichner G, Kögl C, Leitner G, Madl J, Mair P, Pizzulli A, Sölva E, Spögler E, Stockner W, Tratter W (2017) Ergänzungen und Korrekturen zum Katalog der Gefäßpflanzen Südtirols (7). Gredleriana 17: 29-38.

Zavatti S (1966) La coltivazione degli agrumi nelle Marche meridionali. Bollettino della Società Geografica Italiana, serie 9 5: 3-6.

Zohary D, Hopf M (2000) Domestication of plants in the Old World, Ed. 3. Oxford University Press, Oxford.

Zuo SP, Ma YQ, Inanaga S (2008) Ecological adaptation of weed biodiversity to the allelopathic rank of the stubble of different wheat genotypes in a maize field. Weed Biology and Management 8(3): 161-171. https://doi.org/10.1111/j.1445-6664.2008.00292.x

\section{Supplementary material I}

\section{Supplementary data}

Authors: Gabriele Galasso, Fabrizio Bartolucci

Data type: species data

Explanation note: 1. Nomenclature updates; 2. Note updates; 3. Distribution updates; 4. Synonyms, misapplied or included names.

Copyright notice: This dataset is made available under the Open Database License (http://opendatacommons.org/licenses/odbl/1.0/). The Open Database License $(\mathrm{ODbL})$ is a license agreement intended to allow users to freely share, modify, and use this Dataset while maintaining this same freedom for others, provided that the original source and author(s) are credited.

Link: https://doi.org/10.3897/italianbotanist.6.30560.suppl1 